\title{
Demonstration of Epstein-Barr virus DNA in a previously healthy boy with fulminant hepatic failure*
}

\author{
J.Deutsch ${ }^{1}$, H. Wolf ${ }^{2}$, H. Becker ${ }^{3}$, B.Fuchs ${ }^{3}$, U.Goriup ${ }^{1}$, H.-M.Grubbauer ${ }^{1}$, W.Muntean ${ }^{1}$, \\ Th.Popow-Kraupp ${ }^{4}$, and D.Stünzner ${ }^{5}$ \\ ${ }^{1}$ Universitäts-Kinderklinik Graz, A-8036 Graz, Austria \\ ${ }^{2}$ Max von Pettenkofer Institut der Universität München, D-8000 München, Federal Republic of Germany \\ ${ }^{3}$ Pathologisch-Anatomisches Institut der Universität Graz, Graz, Austria \\ ${ }^{4}$ Institut für Virologie der Universität Wien, Wien, Austria \\ ${ }^{5}$ Hygiene-Institut der Universität Graz, Graz, Austria
}

\begin{abstract}
A previously healthy 9-year-old boy died from acute liver failure during an acute Epstein-Barr virus infection. Epstein-Barr virus DNA could be demonstrated in the liver by Southern blot - and by in situ hybridization techniques. The identification of the virus in the liver suggests a causal relation between the Epstein-Barr virus and the acute massive liver cell necrosis.
\end{abstract}

Key words: Epstein-Barr virus - Liver failure - Infectious mononucleosis - Hepatitis

\section{Introduction}

Infectious mononucleosis is characterized by a clinical syndrome with fever, tonsilllopharyngitis, and enlarged cervical lymph nodes $[12,17,22]$. The diagnosis has usually been based on the demonstration of the typical triad, (1) clinical findings compatible with the disease, (2) more than $50 \%$ mononuclear cells in peripheral blood smears, and (3) the occurrence of heterophilic antibodies [17]. Many children with Epstein-Barr virus (EBV) infection do not present with these classical features. Therefore, the demonstration of specific antibodies of the IgM class in the serum seems necessary to confirm an acute infection with EVB [11].

The liver is usually involved in the disease but fulminant hepatic failure is an unusual finding during the course of infectious mononucleosis $[1,2,9,10]$. It seems to occur more frequently in patients with X-linked recessive lymphoproliferative syndrome $[15,16]$. In the past, demonstration of a causal relation between EBV and liver cell necrosis was not possible. Recently developed techniques of nucleic acid hybridization now allow a correlation between EBV and specific cell types to be shown [24].

\footnotetext{
* In part presented at the 5th International Symposium on Ammonia, Semmering, Austria, May 1984, and at the Jahrestagung of the Österreichische Gesellschaft für Kinderheilkunde, Gmunden, Austria, October 1984

Offprint requests to: J.Deutsch, Universitäts-Kinderklinik Graz, Auenbruggerplatz 30, A-8036 Graz, Austria
}

Abbreviations: $\mathrm{EBV}=$ Epstein-Barr virus; $\mathrm{ALT}=$ alanine amniotransferase; KBR = complement binding reactions
We describe the case of a previously healthy boy with infectious mononucleosis who developed an acute hepatic failure. In this patient EBV was demonstrated in liver tissue taken immediately after death using two different nucleic acid hybridization techniques.

\section{Case report}

A previously healthy 8-year-11-month-old boy presented with a history of fatigue, discomfort, upper abdominal pain and fever $\left(38^{\circ} \mathrm{C}\right)$ of 9 days duration [6]. His parents had noted a darkening of the skin and a dark urine. His physician had noted a swelling of cervical glands, sinusitis and pleural effusions. On the day prior to admission total serum bilirubin was $46 \mu \mathrm{mol} / \mathrm{l}$, the conjugated fraction $39.2 \mu \mathrm{mol} / \mathrm{l}$, alanine aminotransferase (ALT) $306 \mathrm{U} / \mathrm{l}$, and gammaglutamyltransferase $174 \mathrm{U} / \mathrm{l}$. The family history did not reveal any signs of immunodeficiency.

On admission the patient was jaundiced, had enlarged cervical glands, inflamed tonsils with white-yellow stipples, and the liver and spleen were palpable $1.5 \mathrm{~cm}$ below the costal margin [6]. The peripheral blood smear showed $72 \%(=8.7 / \mathrm{nl})$ atypical mononuclear cells (Rieder-Glanzmann). The patient was febrile and treatment was started with erythromycin-succinate and noramidopyriniummethane sulphonate-sodium (Novalgin).

The boy developed clinical and laboratory signs of liver failure (ALT $1372 \mathrm{U} / 1$, asparate aminotransferase $3640 \mathrm{U} /$, bilirubin $145 \mu \mathrm{mol} / 1)$ with severe alterations of the coagulation system: thromboplastin time $18 \%$ (normal $>70 \%$ ), partial thromboplastin time $128 \mathrm{~s}$ (normal $35-55 \mathrm{~s}$ ), thrombin time $128 \mathrm{~s}$ (normal $17-24 \mathrm{~s}$ ), fibrinogen $<50 \mathrm{mg} / \mathrm{dl}$ (normal $>150$ $\mathrm{mg} / \mathrm{dl}$ ), Factor II $13 \%$ (normal $>80 \%$ ), factor V $38 \%$ (normal $>80 \%$ ), factor VII $17 \%$ (normal $>80 \%$ ), factor VIII $120 \%$ (normal $>80 \%$ ) and $39 \%$ respectively, antithrombin III $40 \%$ (normal $>80 \%$ ), thrombocytes $56 / \mathrm{nl}$, on the 6 th day after admission [6]. Erythromycin and antipyretics were withdrawn, and the patient was treated by daily exchange transfusions with fresh blood. Lactulose and neomycin administration was started orally, and he had a short course of silymarin and penicillin. Substitutions with coagulation factor concentrates, vitamin $\mathrm{K}$, and antithrombin III could not improve the coagulation disorder nor prevent further bleeding. After resus- 
citation from a cardiac arrest on the 9th day he developed a terminal renal insufficiency [6] and died on the 15th day of his illness.

Heterophilic antibodies against horse erythrocytes were detected by Monospot (Ortho Diagnostic Systems, Heidelberg, FRG) and IM-Quicktest (Human Corporation, Taunusstein-Neuhof, FRG), and the reaction of Paul-Bunnell (against sheep erythrocytes) was positive at a titre of 1:16. Specific antibodies (EBV-VCA, immune fluorescence) of the IgM class were shown to be positive at a titre of $1: 64$, and antibodies of the $\mathrm{IgG}$ class were shown to be positive at a titre of 1:256 [6]. Infections with ornithosis, influenza A and B, mycoplasma pneumoniae, parainfluenza 1,2,3, Q-fever, mumps, adenovirus, cytomegalovirus, echoviruses or coxsackieviruses were excluded by negative complement binding reactions (KBR), infections with measles or rubella viruses were excluded by negative haemagglutination, toxoplasmosis by negative immune fluorescence and hepatitis $A$ and $B$ were excluded by negative radioimmunoassay.

Antibodies to respiratory syncytial virus, herpes simplex and varicella viruses were shown to be positive at a titre of $1: 10$ (KBR). The serum levels of caeruloplasmin, copper, and alpha $a_{1}$-antitrypsin were within the reference ranges of our laboratory. The total IgM level in serum was $4.02 \mathrm{~g} /$, total $\mathrm{IgG}$ and total levels $\operatorname{Ig} \mathrm{A}$ were normal.

\section{Methods}

A complete postmortem examination was done. Histologic examinations were performed on liver, gall bladder, gastrointestinal tract, spleen, lymph nodes, lung, kidney, skin and brain sections (routine HE, PAS, trichrome staining, additional staining of liver sections with Giemsa, diastase-PAS, iron-staining and reticulin-staining). Portions of liver tissue were frozen at $-70^{\circ} \mathrm{C}$ and were stored for 1 month, until nucleic acid hybridization tests were performed. These tests were based either on DNA extracted from tissue (Southern blot, [19]) or were directly performed on sections of frozen tissue (in situ hybridization). The tissue-derived DNA was denatured to yield single-stranded DNA, incubated with equally single-stranded radioactively labelled viral DNA, thoroughly washed and exposed to autoradiography. Positive hybridization signals were regarded as markers for the presence of viral DNA.

1) Procedure of Southern blot hybridization [18]. Liver cell DNA was extracted, digested with Bam $\mathrm{H} 1$ endonuclease, separated on a $0.8 \%$ agarose gel denatured with $0.5 \mathrm{~N} \mathrm{NaOH}$, neutralized and transferred to a nitrocellulose filter by blotting. To determine the sensitivity, Raji-cell DNA was included as a control. According to reassociation kinetic experiments, each Raji cell contains 50 copies of EBV-DNA [25], slot 1: $20 \mu \mathrm{g}$, slot 2: $2 \mu \mathrm{g}$, slot 3: $0.4 \mu \mathrm{g}$, slot 4: $0.2 \mu \mathrm{g}$, and was processed in the same way. The blots were incubated at $68^{\circ} \mathrm{C}$ in $6 \times \mathrm{SSC}$, $0.5 \%$ SDS, $5 \times$ Denhardt's solution [5] with the addition of $100 \mu \mathrm{g} / \mathrm{ml}$ denatured calf tyhmus DNA. After $4 \mathrm{~h}$ the excess prehybridization mix was removed, ${ }^{125}$-labelled EBV-specific single-stranded hybridization probe MEBWS7 added and the incubation continued for another $16 \mathrm{~h}$. After hybridization the filter was washed at $68^{\circ} \mathrm{C}$ in several changes of $2 \times \mathrm{SSC}$, dried and exposed for $12 \mathrm{~h}$.

The hybridization probe was derived by subcloning an internal repeat of EBV-DNA (W-Band after digestion with Bam HI) after SauIII a digestion into the double-stranded replicative form of $\mathrm{m} 13 \mathrm{mp} 8$ bacteriophage. The infected bacteria release recombinant $\mathrm{m} 13$ phage containing singlestranded recombinant DNA. This DNA can be labelled efficiently (specific activity $5 \times 10^{8} \mathrm{cpm} / \mu \mathrm{g}$ ) in the presence of $\mathrm{TI}^{3+}$ with $\mathrm{I}^{125}$ in a chemical reaction [8].

2) Procedure of in situ hybridization [23]. Frozen sections of liver tissue $8 \mu \mathrm{m}$ thick were fixed in a solution containing 3 parts methanol and 1 part concentrated acetic acid, incubated in $2 \times \operatorname{SSC}(1 \times \mathrm{SSC}=0.15 \mathrm{M}$ sodium chloride, $0.015 \mathrm{M}$ sodium citrate) at $70^{\circ} \mathrm{C}$ for $30 \mathrm{~min}$ and treated with proteinase$\mathrm{K}$ at $37^{\circ} \mathrm{C}$ for $15 \mathrm{~min}$. Immediately before hybridization the preparations were denatured in $0.1 \times \mathrm{SSC}$ at $98^{\circ} \mathrm{C}$ for $3 \mathrm{~s}$, chilled in the same buffer at $0^{\circ} \mathrm{C}$ and dried.

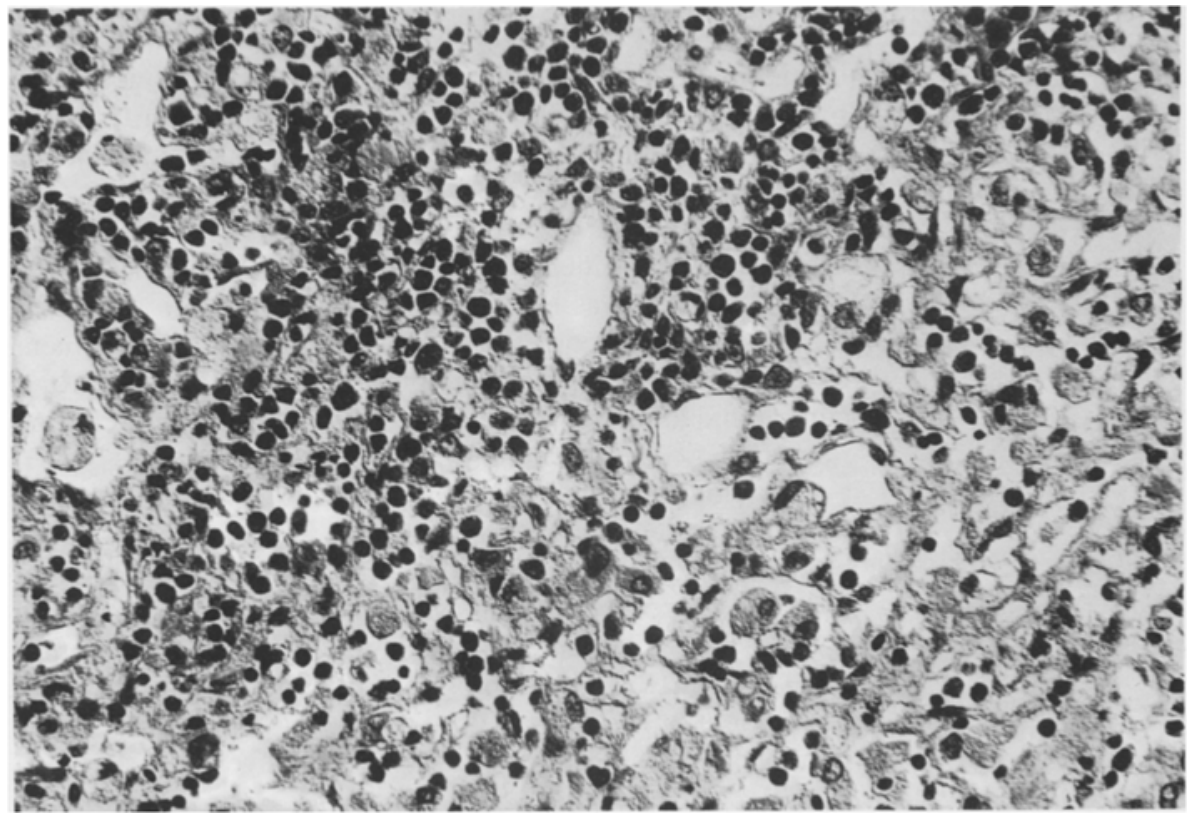

Fig. 1. Postmortem punctate of the liver, trichrom, $324 \times$. Mononuclear cell infiltrates, necrosis of Kupffer cells and of liver cells 
The hybridization probe contained $10^{5} \mathrm{cpm}{ }^{3} \mathrm{H}$-labelled EBV-DNA with a specific activity of about $5 \times 10^{6} \mathrm{cpm} / \mu \mathrm{g}$ in $50 \%$ formamide, $0.6 M$ sodium chloride, $10 \mathrm{~m} M$ Tris- $\mathrm{HCl}$, $\mathrm{pH} 7.5,1 \mathrm{~m} M$ EDTA, $100 \mu \mathrm{g} / \mathrm{ml}$ calf thymus DNA, $1 \mathrm{mg} / \mathrm{ml}$ bovine serum albumin, $1 \mathrm{mg} / \mathrm{ml}$ tRNA, $100 \mu \mathrm{g} / \mathrm{ml}$ Poly A, $0.02 \% \mathrm{wt} / \mathrm{vol}$ polyvinylpyrrolidone, $0.02 \% \mathrm{wt} / \mathrm{vol}$ Ficoll. The preparations were covered by $10 \mu$ of this solution enclosed under a cover slip and sealed with Fixogum (Marabuwerke, Tamm, FRG). The hybridization was continued at $40^{\circ} \mathrm{C}$ for $4 \mathrm{~h}$. The covering was then removed and the sections washed in five changes of formamide buffer (identical to hybridization solution, but without added polyanions) for a total of $15 \mathrm{~h}$, rinsed with $2 \times S S C$, and dried. Then the preparations were dipped into Kodak-NTB emulsion (diluted $1: 1$ in $6 \mathrm{mM}$ ammonium acetate, $40^{\circ} \mathrm{C}$ ), dried and exposed at $4^{\circ} \mathrm{C}$ for 3 weeks. After development (Kodak-D-19 X-ray-film developer) they were stained with Giemsa.

\section{Results}

The postmortem examination revealed a necrosis of $95 \%$ of liver parenchyma with little regeneration in the periphery of liver lobules (Fig. 1). A few proliferating bile ductules were seen. Portal triads and sinusoids were massively infiltrated by

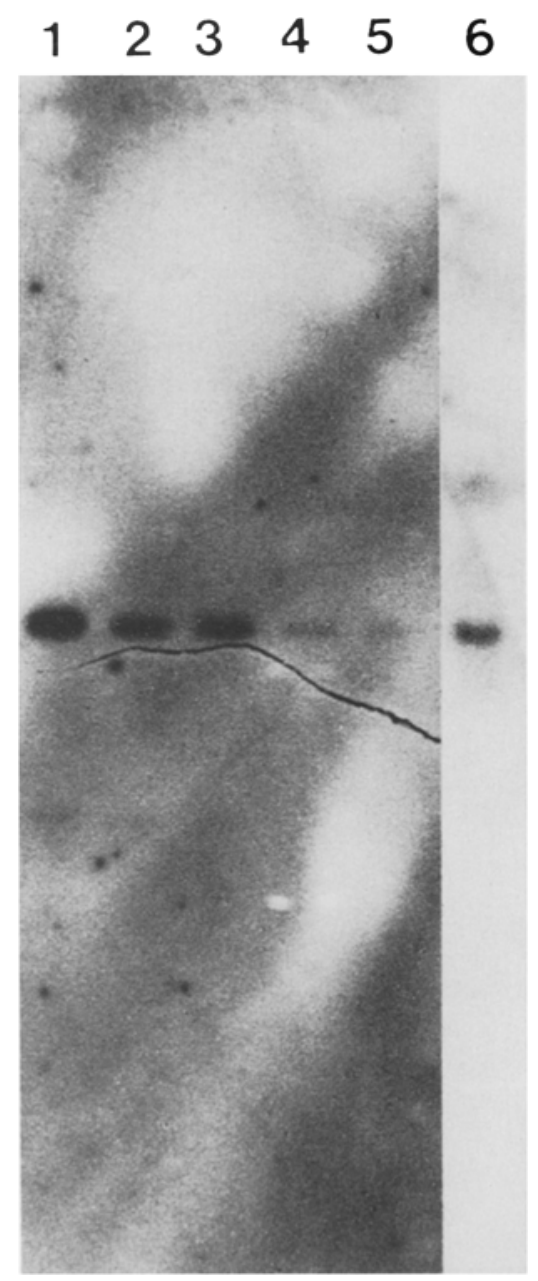

Fig. 2. Southern blot hybridization (W S7ss DNA $125 \mathrm{~J}$ ): positions 1-5: Raji/BamHI $2 \mu \mathrm{g}, 1 \mu \mathrm{g}, 0.5 \mu \mathrm{g}, 0.2 \mu \mathrm{g}, 0.1 \mu \mathrm{g} / \mathrm{slot}$. Position 6: patient H.T., liver tissue DNA $/$ Bam HI $10 \mu \mathrm{g} / \mathrm{slot}$ monocytes and histiocytes. Kupffer cells were enlarged and showed single necroses [6]. There was no cholestasis, no fat depositions or infiltration by eosinophilic leucocytes.

The skin was jaundiced and exhibited petecchial bleeding. Massive bleeding was also seen into the peritoneum and peritoneal cavity, into gall bladder wall and cavity, into gastrointestinal tract, lymph nodes, lungs, myocardium, subepicardially and subendocardially, and into the kidneys. The kidneys showed tubular epithelial necroses [6]. A severe cerebral oedema was noted.

\section{Hybridization studies}

The autoradiographic pictures of "Southern blot" (Fig. 2) as well as of in situ hybridization (Fig. 3) showed a positive result. Because $0.5 \mu \mathrm{g}$ Raji DNA (50 viral genomes per cell) shows a hybridization signal similar to $10 \mu \mathrm{g}$ patient liver DNA the EBV genome content per average liver cell is 2.5 . The black granules in Fig. 3 were caused by the radiation generated by the decay of radioactively labelled viral test DNA (EBV-DNA). This single-stranded test DNA was specifically bound to the complementary strands of "resident" EBV-DNA and formed a double-stranded EBV-DNA sequence. The granules could not be allocated to a certain cell type due to damaged cell structures caused by tissue necrosis and preparation artefacts.

\section{Discussion}

Liver involvement in acute EBV infections occurs in up to $95 \%$ of patients between the 6 th and 15 th day of illness and is usually mild [17].

Harries and Ferguson reported two instances of fulminant hepatic failure in infants [9]. Their diagnosis was based on clinical and laboratory features and on the demonstration of heterophilic antibodies in the older girl. Both children died on the 26th and 28th days, respectively. Recently, another girl aged 14 years had been reported to have died from fulminant hepatic failure during the acute stage of an EBV infection [10]. The diagnosis was confirmed serologically by an EBV VCA-IgM titre of 1:640, but a postmortem examination was not performed. There is no doubt that our patient suffered from an acute EBV infection. The clinical picture (tonsillitis, enlargement of cervical glands), peripheral blood smears, the presence of heterophilic antibodies in two different tests and specific antibodies of the IgM type confirm this infection [6, $11,17,22]$.

In male patients with $\mathrm{X}$-linked lymphoproliferative syndrome a high incidence of massive hepatic necrosis during EBV infections was encountered [15, 16]. Purtilo suggested that immunodeficiency states are necessary for development of an acute liver failure [16]. In our patient, family history, clinical and laboratory data made the diagnosis of pre-existing immunodeficiency very unlikely.

Histologically, the liver involvement is usually characterized by a dense infiltration of portal triads and sinusoids by monoclear cells, by an activation of Kupffer cells and by focal liver cell necrosis [20]. Massive hepatic necroses have rarely been seen in adults $[1,2]$ and in children without immunodeficiencies $[10,15]$. Histological examination of the liver in our patient suggested EBV as a cause of the liver disease, there were no indications of drug-induced liver disease $[7,14$, $21,27]$. 


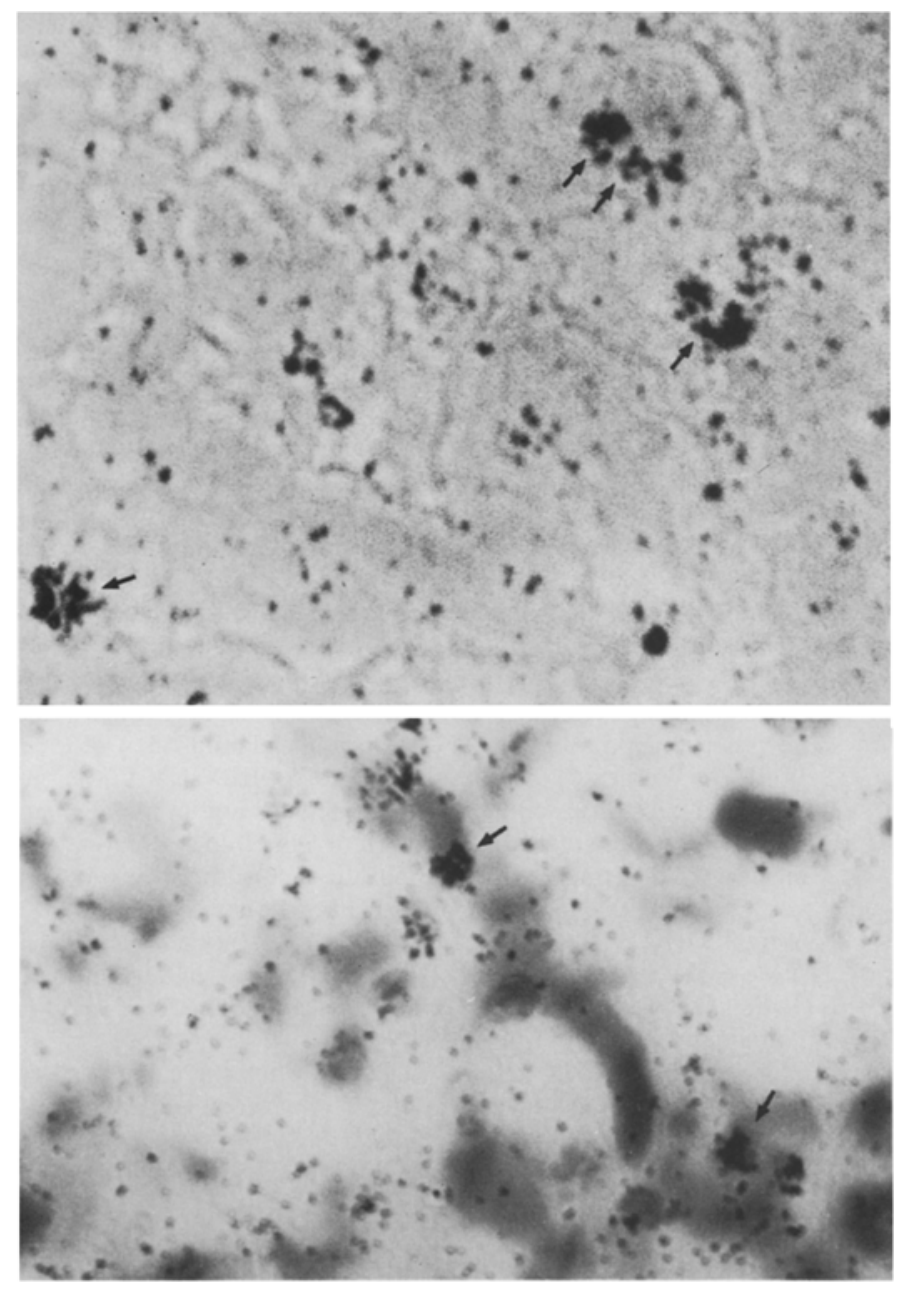

Since massive hepatic necroses, as mentioned above, have only rarely been reported, the identification of EBV in liver tissue seemed necessary to support the diagnosis. Nucleic acid hybridization techniques have been used successfully to demonstrate EBV-DNA in tumour cells of nasopharyngeal carcinoma and in poorly differentiated carcinomas of the tonsils [23]. These methods are based on the ability of singlestranded viral test DNA to form stable double strands with other nucleic acids with complementary sequences of at least five successive nucleotides [24]. Highly specific hybridization probes are obtained by cloning of viral DNA in plasmid vectors; cross reactions with closely related viruses can then be excluded by selecting appropriate fragments [24]. The sensitivity of the test system is determined by the specific radioactivity of the tracer DNA. In the case of in situ hybridizations the multiplying effect of the transcription of active viral genes can be used to achieve higher signals. In these preparations artefacts produced by DNA-binding proteins or local desiccations cannot completely be excluded [24]; therefore, it is preferable to use another independent technique to confirm the results. In our case we used purified DNA digested with restriction enzymes for the detection of viral sequences. The use of purified DNA excludes protein-mediated artefacts and restriction enzymes upon gelelectrophoresis create highly specific bands detectable with specific hybridization.

Southern blot hybridization and in situ hybridization were used for the first time to demonstrate EBV in the liver tissue

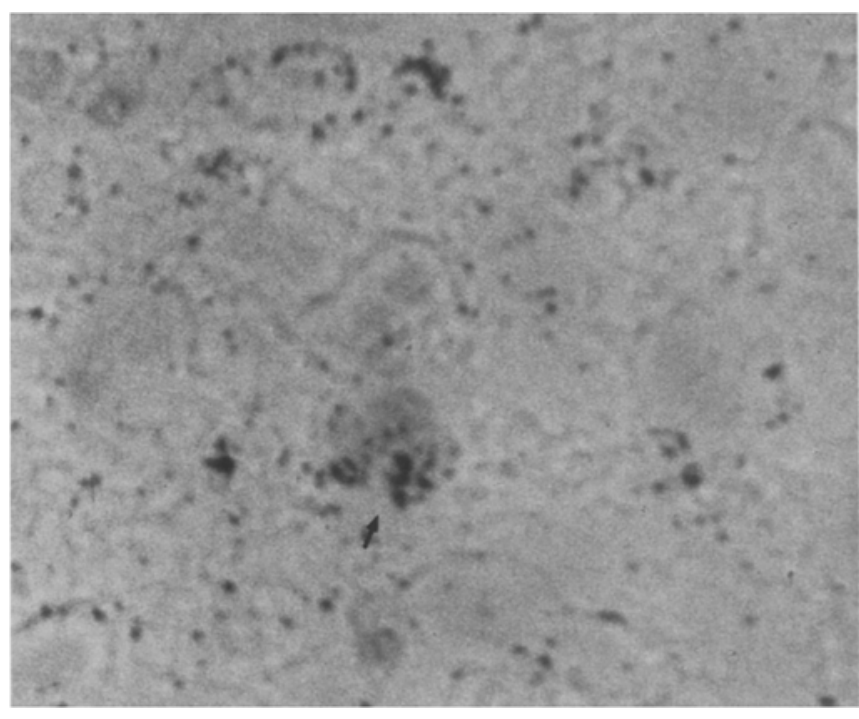

Fig.3. In situ hybridization of liver tissue of patient H.T. Giemsa, $188 \times$. Single-stranded test DNA is specifically bound to singlestranded wild-type EBV-DNA to form a double-stranded EBV-DNA sequence (arrows)

of a patient. The demonstration of highly concentrated EBVspecific DNA in liver tissue confirms the presence of replicative Epstein-Barr viruses and suggests a causal relation between EBV and the acute hepatic necrosis. However, the pathologic mechanism of the massive necrosis of liver cells remains unclear. Immunologic mechanisms may play a role. The virus seems to enter the body in the nasopharynx and rapidly colonizes B-lymphocytes. This causes a T-cell and antibody response to terminate the infection [26]. Some $T$-cell defects apparently induced by EBV $[4,13]$ and the frequency of massive hepatic necrosis in patients with X-linked lymphoproliferative syndrome and EBV infection $[15,16]$ support this theory.

Unfortunately, the virus could not be allocated to a certain cell type. It possibly infiltrates the liver within lymphocytes. Whether it infiltrates the parenchymal cells of the liver in a similar way to epithelial cells of carcinomas $[3,23]$ and whether it exhibits a direct toxic effect on the liver cell remains to be elucidated.

\section{References}

1. Ainley NJ (1949) Fatal case of infectious mononucleosis with extensive zonal necrosis of the liver. Ulster Med $\mathbf{J} 18: 219-224$

2. Allen UR, Bass BH (1963) Fatal hepatic necrosis in glandular fever. J Clin Pathol 16:337-341

3. Bayliss J, Wolf $H$ (1981) An Epstein-Barr virus early protein induces cell fusion. Proc Natl Acad Sci 78:7162-7165 
4. Crawford DH, Epstein MA, Achong BG, Finerty S, Newman J, Liversedge S, Teddler RS, Stewart JW (1979) Virological and immunological studies on a fatal case of infectious mononucleosis. J Infect 1:37-48

5. Denhardt DT (1966) A membrane-filter technique for the detection of complementary DNA. Biochem Biophys Res Commun 23: 641-645

6. Deutsch J, Becker H, Goriup U, Grubbauer HM, Muntean W, Popow-Kraupp TH, Stünzner D (1984) Fatal hepatic necrosis due Epstein-Barr-Virus. In: Kleinberger G, Ferenci P, Riederer P, Thaler $\mathrm{H}$ (eds) Advances in hepatic encephalopathy and urea cycle Diseases. 5th Int Symp on Ammonia, Karger, Basel, pp 749-754

7. Diehl AM, Latham P, Bointnott JK, Mann J, Maddrey WC (1984) Cholestatic hepatitis from erythromycin ethylsuccinate. Am J Med 76:931-934

8. Gu S, Wolf $H$, Zeng $Y$, Hang Y (1985) Detection of EBV-DNA in epithelial cells from nasopharyngeal carcinoma by in situ hybridization. Chinese J Virol 1:126-129

9. Harries JT, Ferguson AW (1968) Fatal infectious mononucleosis with liver failure in two sisters. Arch Dis Child 43:480-485

10. Hart GH, Thompson WR, Schneider J, Davis NJ (1984) Fulminant hepatic failure and fatal encephalopathy associated with Epstein-Barr virus infection. Med J Aust 141:112-113

11. Henle W, Henle G (1979) Epstein-Barr-Virus. In: Spiess H (ed) Virusdiagnostik für Klinik und Praxis. Tagungsbericht der Deutschen Vereinigung zur Bekämpfung der Viruskrankheiten e.V., pp 39-47

12. Lang DJ (1981) Infectious mononucleosis (Epstein-Barr-Virus). In: Feigin RD, Cherry JD (eds) Textbook of pediatric infectious diseases. Saunders, Philadelphia London, pp 1196-1200

13. Lantorp K, Wahren B, Hanngren $\AA$ (1972) Infectious mononucleosis and depression of cellular immunity. Br Med J 4:668-669

14. Lunzer MR, Huang SN, Ward KM, Sherlock S (1975) Jaundice due to erythromycin estolate. Gastroenterology 68:1284-1291

15. Purtilo DT, Paquin L, DeFlorio D, Virzi F, Sakhuja R (1979) Immunodiagnosis and immunopathogenesis of the $\mathrm{X}$-linked recessive lymphoproliferative syndrome. Semin Hematol 16:309-343

16. Purtilo DT (1981) Fulminant hepatic failure in childhood. Br Med J 282:69
17. Rapp CE Jr, Hewetson JF (1978) Infectious mononucleosis and the Epstein-Barr virus. Am J Dis Child 132:78-86

18. Richter W, Gu SY, Seibl R, Wolf H (1983) A new method for examination of carcinomas of the nasopharynynx. In: Prasad $U$, Ablashi DV, Levine PH, Pearson GR (eds) Nasopharyngeal carcinoma - current concepts. Int Symp on Nasopharyngeal Carcinoma, Univ Malaya Press, Kuala Lumpur, pp 25-32

19. Southern EM (1980) Gel electrophoresis in restriction fragments. In: Wu R (ed) Methods in enzymology, vol 68. Academic Press, New York, pp 152-176

20. Thaler H (1982) Leberkrankheiten. Springer, Berlin Heidelberg New York

21. Viteri AL, Greene JF Jr, Dyck WP (1979) Erythromycin ethylsuccinate-induced cholestasis. Gastroenterology 76:1007-1008

22. Watson DH (1984) The herpesviruses. In: Wilson G, Miles A, Parker MT (eds) Principles of bacteriology, virology and immunity, vol 4. Brown F, Wilson G (eds) Virology. Arnold, London, pp 184-212

23. Wilmes E, Wolf H, Haus M (1983) Tonsillenkarzinome und Epstein-Barr-Virus. Laryngol Rhinol Otol 62:586-589

24. Wolf H (1981) Die Verwendung verschiedener NukleinsäureHybridisierungstechniken am Beispiel von Epstein-Barr-Virus korrelierten Erkrankungen. Verh Dtsch Ges Pathol 65:47-57

25. Wolf H, Werner J, ZurHausen H (1975) EBV-DNA in nonlymphoid cells of nasopharyngeal carcinomas and in a malignant lymphoma obtained after inoculation of EBV into cottontop marmosets. Cold Spring Harbor Symposium on Quantitative Biology, vol XXXIX: 791-796. Cold Spring Harbor Laboratory

26. Wright DH (1979) Involvement of the liver by lymphoreticular disease: In: Wright R, Alberti KGMM, Kartan S, MillwardSadler GH (eds) Liver and biliary disease. Saunders, London Philadelphia Toronto, pp 926-940

27. Zafrani ES, Ishak KG, Rudzki C (1979) Cholestatic and hepatocellular injury associated with erythromycin esters. Dig Dis Sci 24: 385-396

Received February 12, 1985 / Accepted August 2, 1985 